\title{
Effects of Urbanization on Stream Ecosystems
}

The National Water-Quality Assessment (NAWQA) Program of the U.S. Geological Survey (USGS) is investigating the effects of urbanization on stream ecosystems in 15 metropolitan areas. Assessments began in 1999 in the metropolitan areas of Anchorage, Alaska; Birmingham, Alabama; Boston, Massachusetts; Chicago, Illinois; Cincinnati-Dayton, Ohio; Los Angeles, California; Philadelphia, Pennsylvania; Trenton, New Jersey; and Salt Lake City, Utah. Additional studies began in 2001 in Atlanta, Georgia; Reno-Sparks, Nevada; Dallas-Fort Worth, Texas; Denver, Colorado; RaleighDurham-Chapel Hill, North Carolina; Milwaukee, Wisconsin; and Portland-Salem-Eugene, Oregon. In all of these studies, urbanization is defined as the conversion from rural land uses to residential and commercial uses that are typical of recent, generally sprawling, urban-growth patterns.

\section{Specific questions addressed by all studies}

- As watersheds are urbanized, what is the magnitude and pattern of response in stream hydrology, water chemistry, and biological communities? Are there threshold levels of urbanization at which stream ecosystems degrade more rapidly?

- What watershed characteristics, such as basin slope, geology, and soils, are closely related to hydrologic, chemical, and biological responses to urbanization?

- How do biological responses to urbanization vary among the diverse environmental settings of these metropolitan areas?

- What are the susceptibilities of specific aquatic organisms to water-quality degradation caused by urbanization?

- What are the best measures to use for monitoring water quality in watersheds that are becoming increasingly urbanized?

\section{Preliminary findings}

Data from the 1999 studies are being compiled and interpreted; findings will be reported in journals and USGS reports in 2003. Preliminary analysis indicates that:

- Rapid degradation of stream ecosystems occurs early in the process of watershed urbanization. For example, in Anchorage, invertebrate communities that are sensitive to pollution and habitat modifications declined when about 5 percent of land cover in the watershed was converted to "impervious area," such as roads, parking lots, and houses.

- Early, rapid degradation is associated with processes, such as deforestation, that alter hydrology, stream temperature, and habitat. In some areas, these physical factors severely degrade biological communities before nutrients and other contaminants from non-point sources reach concentrations that may further degrade the communities.

- The magnitude of stream ecosystem response generally is greater when forests or rangeland are urbanized than when agricultural areas planted in row crops are urbanized.

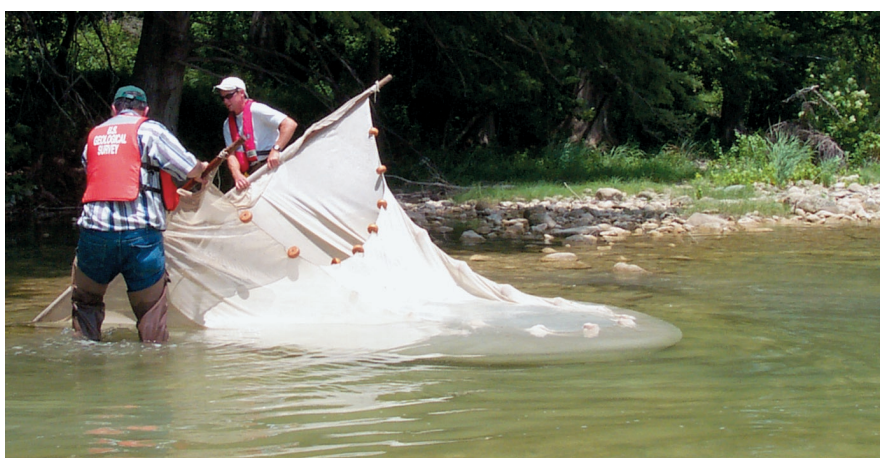

USGS biologists collecting fish for tissue analysis and community status assessment.

\section{How this information can be used}

These studies will better define the interrelationships among water quality, stream hydrology and habitat, and ecosystems. In addition, the studies will lead to improved and comparable techniques for biological monitoring, and to the development of key indicators of the effects of urbanization on environmental quality. Information on the magnitude and pattern of degradation of stream ecosystems will help urban planners and other stakeholders prioritize streams for restoration. Understanding the effects of habitat disturbance, in addition to chemical contamination, within a given setting will help clarify the most appropriate strategy for managing, protecting, and restoring urban streams.

By Carol Couch and Pixie Hamilton

See map and contact information on back 


\section{Locations of 15 metropolitan areas where NAWOA is studying the effects of urbanization on stream ecosystems}

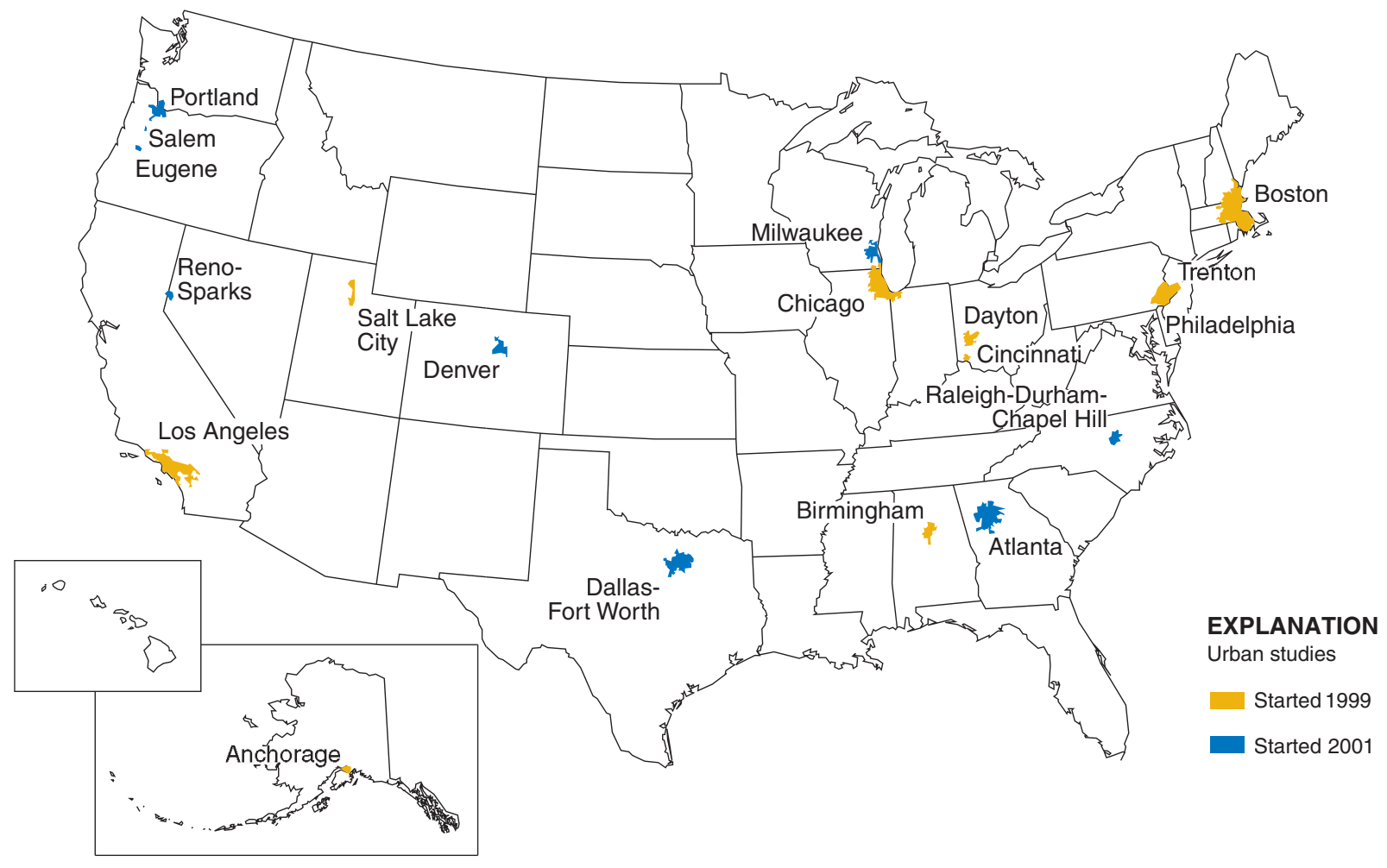

\section{Metropolitan Area}

Anchorage, AK

Atlanta, GA

Birmingham, AL

Boston, MA

Reno-Sparks, NV

Chicago, IL

Dallas-Fort Worth, TX

Cincinnati-Dayton, $\mathrm{OH}$

Denver, $\mathrm{CO}$

Los Angeles, CA

Milwaukee, WI

Philadelphia, PA/Trenton, NJ

Portland-Salem-Eugene, OR

Raleigh-Durham-Chapel Hill, NC

Salt Lake City, UT

\section{Contact name, phone, and email}

Steve Frenzel

Brian Hughes

Brian Atkins

Keith Robinson

Michael Rosen

George Groschen

Bruce Moring

Gary Rowe

Cathy Tate

Ken Belitz

Charles Peters

Jeff Fischer

Denny Wentz

Douglas Harned

Kidd Waddell
(907) 786-7107

(770) 903-9162

(334) 213-2332

(603) 226-7809

(775) $887-7683$

(217) 344-0037

(512) 927-3585

(614) 430-7729

(303) 236-4882

(858) 637-6850

(608) 821-3810

(609) 771-3953

(503) 251-3296

(919) 571-4024

(801) 908-5065

\begin{abstract}
sfrenzel@usgs.gov wbhughes@usgs.gov jbatkins@usgs.gov kwrobins@usgs.gov mrosen@usgs.gov gegrosch@usgs.gov jbmoring@usgs.gov glrowe@usgs.gov cmtate@usgs.gov kbelitz@usgs.gov capeters@usgs.gov fischer@usgs.gov dawentz@usgs.gov daharned@usgs.gov kwaddell@usgs.gov
\end{abstract}

\section{Contact for additional information:}

Carol Couch, National Ecological Synthesis Project

U.S. Geological Survey, 413 National Center, 12201 Sunrise Valley Dr., Reston, Virginia, 20192

(703) 648-5074 (phone)

(703) 648-6693 (fax)

cacouch@usgs.gov

\section{Internet access to supporting NAWOA technical and program information:}

http://water.usgs.gov/nawqa 